\title{
Health benefits of cycle ergometer training for older adults over 70: a review
}

\author{
Walid Bouaziz ${ }^{1,2^{*}}$, Elise Schmitt ${ }^{1,2}$, Georges Kaltenbach', Bernard Geny ${ }^{2,3}$ and Thomas Vogel ${ }^{1,2}$
}

\begin{abstract}
As the number of older adults continues to increase worldwide, more attention is being paid to geriatric health care needs, and successful ageing is becoming an important topic in the medical literature. A preventive approach to the care of older adults is thus a priority in our aging societies. The purpose of this study was to update evidence for the health benefits of cycle ergometer training for older adults over 70 . We searched online electronic databases up to September 2014 for original observational and intervention studies on the relationship between cycle ergometer training and health among older patients over 70. Twenty-five studies examined interventions aimed specifically at promoting cycling for older adults over 70 . These studies reported a positive effect on the prevention of cardiovascular disease, and a significant improvement in metabolic responses. Improving functional status, muscle strength and cognitive performance are also well established. Overall, this review demonstrates a positive effect of cycle ergometer training with functional benefits and positive health outcomes for older adults over 70. Based on this evidence, clinicians can now encourage older adults to profit from the health benefits of cycle ergometer training to be able to pursue their daily activities independently.
\end{abstract}

Keywords: Health benefits, Cycle ergometer training, Older adults, Over 70

\section{Introduction}

Physical activity (PA) is a modifiable behavior associated with health, functional status, and longevity, and encouraging a physically active lifestyle has become an accepted public health objective $[1,2]$.

Concerning the general population, it is well known that regular physical activity (PA) ensures primary and secondary prevention of several chronic conditions [3]. Indeed, a large scale longitudinal 8-year study found that every additional $15 \mathrm{~min}$ of daily PA up to $100 \mathrm{~min}$ per day resulted in a further $4 \%$ decrease in mortality from any cause [4].

The prevalence of sedentary behavior is higher in older adults, and is an independent health risk factor lead to an increase in the risk of developing numerous chronic diseases as well as all-cause mortality $[5,6]$. The risk of all of these diseases can be reduced by increased physical activity [7]. Further, evidence suggests that for older people, PA in later life can extend the period of active

\footnotetext{
* Correspondence: walid.bouaziz.88@gmail.com

${ }^{1}$ Geriatric Department, University Hospital, Strasbourg, France

${ }^{2}$ Department of Physiology and EA-3072, Faculty of Medicine, Strasbourg

University, Strasbourg, France

Full list of author information is available at the end of the article
}

independent living, reduce disability and improve the quality of life [8]. Increasing PA thus helps minimize the burden on health and social care by improving healthy ageing $[9,10]$.

It is well established that endurance exercise training is an effective strategy in older adults to reduce body fat mass, increase whole-body insulin sensitivity, and reduce the risk of cardiovascular disease [3, 11]. It is also an effective strategy to protect older adults from falls and from some cancers (especially breast and colon cancer) [3].

The effectiveness of different modes of endurance exercise training on health such as cycle ergometer training (CET) [12], walking or jogging [13] and treadmill training [14] has been demonstrated in several studies. Among these modes of exercise, CET is particularly attractive because it is relatively easy and safe and causes no related injuries [15].

CET is usually a major component of any endurance exercise program that seeks to improve aerobic capacity and cardiovascular health [16]. Cycling is a healthy form of endurance exercise and, as a non-weight bearing activity, has less impact on the joints and is thus less 
stressful for the body than jogging or other running sports [17]. In addition, CET does not require as much postural control as walking on a treadmill and may be a better alternative for individuals with poor balance [18]. Finally, CET is feasible even for frail older individuals [19].

Up to now, the health benefits of CET for the general population are well established [20-22]. However, the effect of CET is less well documented in older adults [23-26] particularly those aged over $70[27,28]$. The aim of this review was thus to assess the health benefits of CET in this group.

\section{Methods}

\section{Literature search}

We conducted a systematic search for observational and intervention studies that examined the relation between cycle exercise training and the health of older adults published between April 1983 and June 2013. Published and peer-reviewed articles in English language journals were identified in electronic databases and on reference lists of articles available to the authors of this review.

The search terms 'exercise training, endurance training, or aerobic training and cycle ergometer, cycling or bicycle and health, health benefits and older adults, elderly, very old/elderly, aged, aging, oldest, old and over 70' were combined to search each of the eight electronic databases. The search resulted in a total of 4080 hits: Pubmed Central 3245, Medline 269, Scopus 237, Web of Science 129, SportDiscus 62, Embase 56, CINAHL Plus 50 , Cochrane library 32 . We also searched for previous systematic reviews, websites, and references therein.

\section{Inclusion criteria and selection process}

Based on the article titles and available abstracts, the reports were first evaluated for inclusion using the following criteria:

Original research articles written in English, observational or intervention studies published in peer-reviewed journals with outcomes based on the use of bicycle ergometer, independently reported effects of cycle ergometer training (CET) in adults aged over 70, quantitative measures of CET for any purpose, measures of mortality or morbidity (including disease risk factors) and/or measures of health and cardiovascular function through CET.

Altogether 3964 articles were excluded for the following reasons: absence of controls studies, the outcomes were based on the use of real cycling, the studies focused on cycling injuries and accidents, and the studies evaluated physical activity in general, and not specifically CET.

A total of 116 potentially relevant papers were selected. Two authors independently evaluated them based on the inclusion criteria. This resulted in the additional exclusion of 85 studies. Thirty-one of the originally eligible studies were selected for detailed evaluation of the full text. After exclusion of six more papers based on the unanimous judgment of the two authors, 25 studies were selected for review (Fig. 1).

\section{Data extraction}

The selected studies were sorted according to authors, year of publication, mean age of sample, type of protocol and outcomes. The studies were divided into four groups based on four outcomes: cardiovascular function (Table 1), metabolic outcomes (Table 2), functional status (Table 3), and cognitive function (Table 4).

\section{Results}

Twenty-five controlled trial studies (12 randomized studies [27, 29-38] and 13 non-randomized studies $[28,39-50])$ were identified for the review.

\section{Effects on cardiovascular function \\ Effects on cardio-respiratory fitness}

Specific effects of cycle ergometer training (CET) on cardio-respiratory fitness were reported in eight of the 12 randomized studies [27, 29-35] (Table 1). Indeed, after a moderate endurance program on cycle ergometer, Lovell et al. [27, 29] noted a significant increase in $\mathrm{VO}_{2 \max }$ (15 and $17 \%$ respectively, $p<0.05$ ) in the active group compared to the control group. Similarly, in older patients over 70, Buchner et al. [30] reported a $9 \%$ increase in $\mathrm{VO}_{2 \max }(p<0.05)$ after 78 endurance training sessions, with no significant change in the control group. Older subjects with a lower baseline $\mathrm{VO}_{2 \max }$ showed the greatest improvement in $\mathrm{VO}_{2 \max }(+29 \%, p<0.05)$ after CET, as shown by Babcock et al. [31]. In a small group of older people, Malbut et al. [32] reported a $15 \%$ increase in $\mathrm{VO}_{2 \max }$ among women, and no significant change among men, after a 24-week program of CET at $75-80 \%$ of $\mathrm{VO}_{2 \max }$. In two small randomized studies, Coker et al. [33, 34] observed a similar increase in aerobic fitness in both moderate and intermittent exercise groups as evidenced by a respective increase of $14 \%$ and $21 \%$ in $\mathrm{VO}_{2 \max }$, as the result of CET. Conversely, Mangione et al. [35], reported no significant change in $\mathrm{VO}_{2 \max }$ in older patients in both high and low intensity cycle training groups.

Concerning the non-randomized studies, 11 of the 13 studies were conclusive [28, 40-48] (Table 1). A recent study by Vogel et al. [28] reported that a short-term intermittent cycling exercise program (36 min per session, 2 times per week for 9 weeks) led to a significant increase in $\mathrm{VO}_{2 \max }(16.6 \%$ and $8.9 \%$ in older women and men respectively, all $p<0.05)$. Harber et al. [40] reported a significant improvement $(29 \%, p<0.05)$ in the $\mathrm{VO}_{2 \max }$ of older adults after 12 weeks of CET. In 


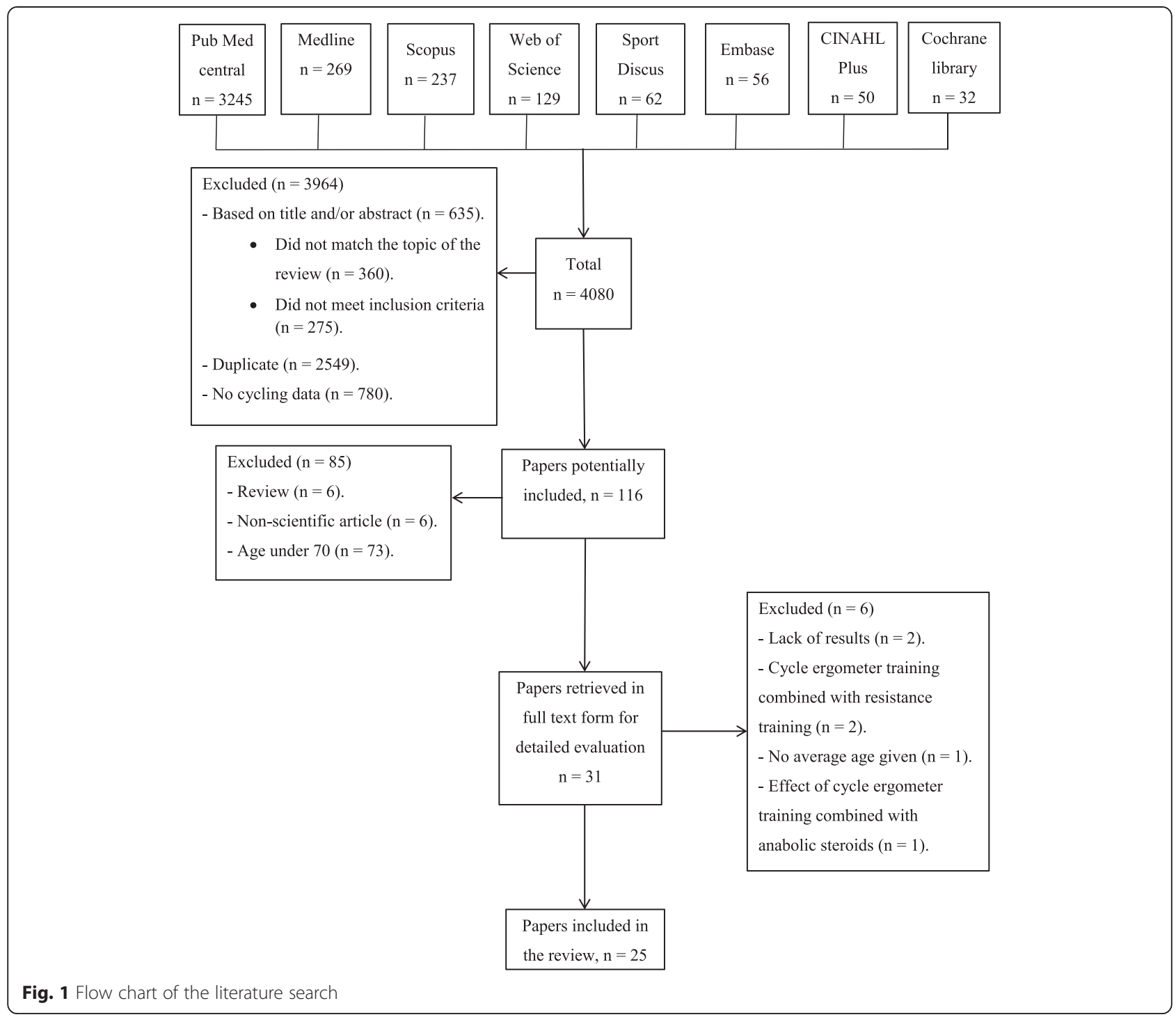

a small study, Perini et al. [41] also reported an $18 \%$ $(p<0.05)$ increase in $\mathrm{VO}_{2 \max }$ after 8 weeks of CET. Other data suggested that CET in people over 70 resulted in an $11 \%(p<0.01)$ increase in $\mathrm{VO}_{2 \max }$ [42]. Moreover, short-term CET led to a significant $16 \%$ $(p<0.001)$ improvement in $\mathrm{VO}_{2 \max }$ in 188 older subjects (73 \pm 5 years old) [43]. Using data from two studies including older patients, Charifi et al. [44, 45] observed a $13.5 \%$ increase in $\mathrm{VO}_{2 \max }(p<0.05)$, after 56 sessions of CET. In a small study involving six older subjects (74 \pm 2 years), Sial et al. [46] reported a $21 \%$ increase in $\mathrm{VO}_{2 \max }(p<0.01)$ after 16 weeks of $\mathrm{CET}$ at $70-85 \%$ of maximal heart rate $\left(\mathrm{HR}_{\max }\right)$. Following 14 weeks of CET, Pichot et al. [47] observed an $18.6 \%$ increase in the $\mathrm{VO}_{2 \max }(p<0.01)$ among older adults over 70 . Finally in a small study, Bell et al. [48] reported a significant $16 \%$ increase in
$\mathrm{VO}_{2 \max }$ after 36 sessions of CET at 70-85 \% of $\mathrm{VO}_{2 \max }$ performed using a single leg.

According to these studies, moderate to high intensity of personalized CET, i.e., $30 \mathrm{~min}$ a day at least twice a week for a period of nine weeks seems to be useful for improving cardio-respiratory fitness among older adults over 70 .

\section{Effects on blood pressure}

The benefits of CET on blood pressure in older subjects over 70 are less consistent and were reported in five studies [36, 37, 41, 47, 49] (Table 1). In a small randomized trial on healthy normotensive older patients, Nickel et al. [36] noted a significant decrease in systolic blood pressure (SBP) by $8 \%$ after $15 \mathrm{~min}$ and in diastolic blood pressure (DBP) by $4 \%$ after $24 \mathrm{~h}$ of CET at $50 \%$ of heart rate reserve (HRR) in the active group compared to the control 
Table 1 Summary of studies that analyze the effects of cycle ergometer training on cardiovascular function

\begin{tabular}{|c|c|c|c|c|c|}
\hline \multirow[b]{3}{*}{$\begin{array}{l}\text { Author, } \\
\text { year }\end{array}$} & \multirow[b]{3}{*}{$\begin{array}{l}\text { Mean } \\
\text { age } \\
\text { (years) }\end{array}$} & \multirow[b]{3}{*}{ Protocol type } & \multicolumn{3}{|l|}{ Outcomes } \\
\hline & & & \multicolumn{3}{|l|}{ Cardiovascular function } \\
\hline & & & Cardio-respiratory fitness & Blood pressure values & Endurance parameters \\
\hline $\begin{array}{l}\text { Lovell et } \\
\text { al. (2010) } \\
\text { [27] }\end{array}$ & $\begin{array}{l}75.2 \\
\pm 0.8\end{array}$ & $\begin{array}{l}\mathrm{CET} 50-70 \% \text { of } \mathrm{VO}_{2 \max } 30- \\
45 \mathrm{~min} / \mathrm{session} 3 \text { sessions/ } \\
\text { week, } 16 \text { weeks }\end{array}$ & \multicolumn{3}{|l|}{$\begin{array}{l}\text { Training group: } \uparrow \text { in } \mathrm{VO}_{2 \max } \text { (from } 22.6 \\
\pm 0.7 \text { to } 25.9 \pm 0.9 \mathrm{ml} / \mathrm{min} / \mathrm{kg}) \leftrightarrow \text { in } \\
\text { Control group. }\end{array}$} \\
\hline $\begin{array}{l}\text { Vogel et } \\
\text { al. (2011) } \\
{[28]}\end{array}$ & $\begin{array}{l}70.8 \\
\pm 5.2\end{array}$ & $\begin{array}{l}\text { CET5-min stages consisting } \\
\text { of } 4 \mathrm{~min} \text { at } \mathrm{VT}_{1} \text { and } 1 \mathrm{~min} \text { at } \\
90 \% \text { of MTP30 min/session2 } \\
\text { sessions/week, } 9 \text { weeks }\end{array}$ & \multicolumn{2}{|l|}{$\begin{array}{l}\uparrow \text { in the } V_{2} \text { max (from } 16.9 \pm 3.6 \text { to } \\
19.7 \pm 3.6 \mathrm{ml} / \mathrm{min} / \mathrm{kg} \text { ) and (from } 21.4 \\
\pm 5.8 \text { to } 23.3 \pm 6.4 \mathrm{ml} / \mathrm{min} / \mathrm{kg} \text { ), in } \\
\text { older women and men, respectively. }\end{array}$} & $\begin{array}{l}\uparrow \text { in the } \mathrm{VT}_{1} \text { (from } 50.1 \pm 11.5 \text { to } 64.1 \pm 14.4 \mathrm{~W} \text { ) and } \\
\text { (from } 79.3 \pm 25.1 \text { to } 96.1 \pm 29.2 \mathrm{~W} \text { ) in older men and } \\
\text { women respectively. } \downarrow \text { in } \mathrm{HR} \text { at pre-training } \mathrm{VT}_{1} \\
\text { (from } 112 \pm 18 \text { to } 105 \pm 17 \mathrm{bpm} \text { ) and (from } 109 \pm 19 \\
\text { to } 103 \pm 19 \mathrm{bpm} \text { ) in older men and women } \\
\text { respectively. } \downarrow \text { in the lactate concentrations at pre- } \\
\text { training MTP (from } 4.5 \pm 1.7 \text { to } 3.5 \pm 1.0 \mathrm{mmol} \text { ) and } \\
\text { (from } 5.5 \pm 1.9 \text { to } 4.4 \pm 19 \mathrm{mmol} \text { ) in older men and } \\
\text { women respectively. }\end{array}$ \\
\hline $\begin{array}{l}\text { Lovell et } \\
\text { al. (2012) } \\
\text { [29] }\end{array}$ & $\begin{array}{l}75.2 \\
\pm 3.0\end{array}$ & $\begin{array}{l}\text { CET50 to } 70 \% \mathrm{VO}_{2 \max } 30 \text { to } \\
45 \mathrm{~min} / \mathrm{sessionweek/week} \\
16 \text { weeks }\end{array}$ & \multicolumn{2}{|l|}{$\begin{array}{l}\text { Training group: } \uparrow \text { in } \mathrm{VO}_{2 \max }(1.9 \pm 0.1 \\
\text { to } 2.2 \pm 0.1 \mathrm{~L} / \mathrm{min}) \leftrightarrow \text { in Control } \\
\text { group. }\end{array}$} & \\
\hline $\begin{array}{l}\text { Buchner } \\
\text { et al. } \\
\text { (2009) [30] }\end{array}$ & 75 & $\begin{array}{l}\text { CET75 \% of HRR30 to } \\
35 \mathrm{~min} / \mathrm{sessionweek} / \text { week, } \\
24 \text { to } 26 \text { weeks }\end{array}$ & \multicolumn{2}{|l|}{$\begin{array}{l}\text { Training group: } \uparrow \text { in the } \mathrm{VO}_{2 \max } \text { (from } \\
16.6 \pm 4.9 \text { to } 18.1 \pm 2.5 \mathrm{ml} / \mathrm{min} / \mathrm{kg}) . \leftrightarrow \\
\text { in control group. }\end{array}$} & \\
\hline $\begin{array}{l}\text { Babcock } \\
\text { et al. } \\
\text { (1994) [31] }\end{array}$ & $\begin{array}{l}72 \pm \\
4.4\end{array}$ & $\begin{array}{l}\text { CET20 to } 50 \% \text { of } \mathrm{VT}_{2} 40 \mathrm{~min} / \\
\text { sessionweek/week, } 24 \text { weeks }\end{array}$ & \multicolumn{2}{|l|}{$\begin{array}{l}\text { Training group: } \uparrow \text { in } \mathrm{VO}_{2 \max } \text { (from } 1.8 \\
\pm 0.2 \text { to } 2.1 \pm 0.1 \mathrm{~L} / \mathrm{min}) \leftrightarrow \text { in control } \\
\text { group. }\end{array}$} & $\begin{array}{l}\uparrow \text { in } \mathrm{VO}_{2} \text { at } \mathrm{VT}_{1} \text { (from } 1.2 \pm 0.1 \text { to } 1.5 \pm 0.2 \mathrm{~L} / \mathrm{min} \text { ) } \leftrightarrow \\
\text { in } \mathrm{HR} \text { at } \mathrm{VT}_{1} \leftrightarrow \text { in control group: }\end{array}$ \\
\hline $\begin{array}{l}\text { Malbut et } \\
\text { al. (2002) } \\
\text { [32] }\end{array}$ & $\begin{array}{l}81 \pm \\
2.28\end{array}$ & $\begin{array}{l}\text { CET13-15 of RPE13 to } \\
20 \mathrm{~min} / \mathrm{session} 3 \text { to } 6 \\
\text { sessions/week, } 24 \text { weeks }\end{array}$ & \multicolumn{2}{|l|}{$\begin{array}{l}\uparrow \text { in the } V O_{2 \max } \text { of the women's } \\
\text { group (from } 14.5 \pm 2.5 \text { to } 16.2 \pm \\
3.1 \mathrm{ml} / \mathrm{kg} / \mathrm{min}) . \leftrightarrow \text { in the men's } \\
\text { group. }\end{array}$} & $\begin{array}{l}\downarrow \text { in } \mathrm{HR} \text { at } \mathrm{VO}_{2} 10 \text { in the women's group (from } 108 \\
\pm 21 \text { to } 92 \pm 15 \mathrm{bpm} \text { ). } \downarrow \text { in } \mathrm{HR} \text { at } \mathrm{VO}_{2} 10 \text { in the men's } \\
\text { group (from } 97 \pm 11 \text { to } 89 \pm 10 \mathrm{bpm} \text { ). }\end{array}$ \\
\hline $\begin{array}{l}\text { Coker et } \\
\text { al. (2006) } \\
{[33]}\end{array}$ & $74 \pm 1$ & $\begin{array}{l}\text { CET50 or } 75 \% \text { of } \\
\text { VO }_{2 \text { max }} 40 \mathrm{~min} / \text { session } 4 \text { to } 5 \\
\text { sessions } / \text { week, } 12 \text { weeks }\end{array}$ & \multicolumn{2}{|l|}{$\begin{array}{l}\uparrow \text { in the } \mathrm{VO}_{2 \max } \text { for both the } \mathrm{HI} \text { and } \\
\mathrm{Ml} \text { groups (from } 1.4 \pm 0.3 \text { to } 1.6 \pm \\
0.1 \mathrm{~L} / \mathrm{min} \text { ). }\end{array}$} & \\
\hline $\begin{array}{l}\text { Coker et } \\
\text { al. (2009) } \\
{[34]}\end{array}$ & $71 \pm 1$ & $\begin{array}{l}\mathrm{CET} 50 \text { or } 75 \% \text { of } \\
\mathrm{VO}_{2 \text { max }} 40 \mathrm{~min} / \mathrm{session} 4 \text { to } 5 \\
\text { sessions/week, } 12 \text { weeks }\end{array}$ & \multicolumn{2}{|l|}{$\begin{array}{l}\uparrow \text { in the } \mathrm{VO}_{2 \max } \text { for both the } \mathrm{HI} \text { and } \\
\mathrm{Ml} \text { groups (from } 1.4 \pm 0.3 \text { to } 1.6 \pm \\
0.1 \mathrm{~L} / \mathrm{min} \text { ). }\end{array}$} & \\
\hline $\begin{array}{l}\text { Mangione } \\
\text { et al. } \\
\text { (1999) [35] }\end{array}$ & $\begin{array}{l}71 \pm \\
6.9\end{array}$ & $\begin{array}{l}\text { CET40 or } 70 \% \text { HRR25 min/ } \\
\text { sessionweek/week, } 10 \text { week }\end{array}$ & \multicolumn{2}{|l|}{$\begin{array}{l}\leftrightarrow \text { in the } \mathrm{VO}_{2 \max } \text { in both high and } \\
\text { low intensity groups. }\end{array}$} & \\
\hline \multirow[t]{2}{*}{$\begin{array}{l}\text { Harber et } \\
\text { al. (2009) } \\
{[40]}\end{array}$} & 71.1 & $\begin{array}{l}\text { CET60 \% of } P_{\max } 20 \text { to } \\
40 \text { min/sessionweek/week, } \\
12 \text { weeks }\end{array}$ & \multicolumn{2}{|l|}{$\begin{array}{l}\uparrow \text { in the } \mathrm{VO}_{2 \max } \text { (from } 1623 \pm 423 \text { to } \\
1856 \pm 480 \mathrm{ml} / \mathrm{min} \text { ). }\end{array}$} & \\
\hline & $\begin{array}{l}73.9 \\
\pm 3.5\end{array}$ & & $\begin{array}{l}\uparrow \text { in the } \mathrm{VO}_{2 \max } \text { (from } 19.3 \pm 5.2 \text { to } \\
22.7 \pm 4.9 \mathrm{ml} / \mathrm{min} / \mathrm{kg} \text { ). }\end{array}$ & $\begin{array}{l}\downarrow \text { in resting SBP (from } 167 \text { to } 140 \mathrm{mmHg} \text { for men } \\
\text { and from } 148 \text { to } 130 \mathrm{mmHg} \text { for women). } \downarrow \text { in resting }\end{array}$ & \\
\hline
\end{tabular}


Table 1 Summary of studies that analyze the effects of cycle ergometer training on cardiovascular function (Continued)

\begin{tabular}{|c|c|c|c|c|c|}
\hline $\begin{array}{l}\text { Perini et } \\
\text { al. (2002) } \\
{[41]}\end{array}$ & & $\begin{array}{l}\text { CET } 40 \text { to } 100 \% \text { of } \\
\mathrm{P}_{\max } 60 \mathrm{~min} / \mathrm{sessionweek} \\
\text { week, } 8 \text { weeks }\end{array}$ & & $\begin{array}{l}\text { DBP (from } 88 \text { to } 78 \mathrm{mmHg} \text { for men and from } 80 \text { to } \\
72 \mathrm{mmHg} \text { for women). } \leftrightarrow \text { in SBP and DBP on } \\
\text { recovery time. }\end{array}$ & \\
\hline $\begin{array}{l}\text { Haber et } \\
\text { al. (1984) } \\
{[42]}\end{array}$ & 71.1 & $\begin{array}{l}\text { CET60 \% of } P_{\max } 20 \text { to } \\
40 \mathrm{~min} / \mathrm{sessionweek/week,} \\
12 \text { weeks }\end{array}$ & $\begin{array}{l}\uparrow \text { in the } \mathrm{VO}_{2 \max } \text { (from } 1623 \pm 423 \text { to } \\
1856 \pm 480 \mathrm{ml} / \mathrm{min} \text { ). }\end{array}$ & & $\begin{array}{l}\uparrow \text { in the maximum work load (from } 111 \pm 36 \text { to } 129 \\
\pm 29 \mathrm{~W} \text { ). }\end{array}$ \\
\hline $\begin{array}{l}\text { Temfemo } \\
\text { et al. } \\
\text { (2011) [43] }\end{array}$ & $73 \pm 5$ & $\begin{array}{l}\text { CETHR } R_{\text {target }} \text { Corresponding to } \\
\text { the } \mathrm{VT}_{1} 45 \mathrm{~min} / \mathrm{sessionweek/} \\
\text { week, } 8 \text { weeks }\end{array}$ & $\begin{array}{l}\uparrow \text { in the } V O_{2 \max } \text { (from } 13.2 \pm 1.7 \text { to } \\
15.3 \pm 2.1 \mathrm{ml} / \mathrm{min} / \mathrm{kg} \text { ). }\end{array}$ & & $\uparrow$ in the $V_{1}$ (from $9.2 \pm 1.8$ to $10.8 \pm 2.2 \mathrm{ml} / \mathrm{min} / \mathrm{kg}$ ). \\
\hline $\begin{array}{l}\text { Charifi et } \\
\text { al. (2003) } \\
{[44]}\end{array}$ & $73 \pm 3$ & $\begin{array}{l}\text { CET9*4 min } 65 \text { to } 75 \% \\
V_{2 \max }{ }^{*} 1 \text { min } 85 \text { to } 95 \% \\
V_{2 \max } 45 \text { min/session } 4 \\
\text { sessions/week, } 14 \text { weeks }\end{array}$ & $\begin{array}{l}\text { ? in the } \mathrm{VO}_{2 \max } \text { (from } 28.8 \pm 5.9 \text { to } \\
32.7 \pm 5.4 \mathrm{ml} / \mathrm{min} / \mathrm{kg} \text { ). }\end{array}$ & & \\
\hline $\begin{array}{l}\text { Charifi et } \\
\text { al. (2004) } \\
\text { [45] }\end{array}$ & $73 \pm 3$ & $\begin{array}{l}\text { CET9*4 min } 65 \text { to } 75 \% \\
V_{2 \max } 9^{* 1} \min 85 \text { to } 95 \% \\
V_{2 \max } 45 \text { min/session } 4 \\
\text { sessions/week, } 14 \text { weeks }\end{array}$ & $\begin{array}{l}\uparrow \text { in the } \mathrm{VO}_{2 \max } \text { (from } 28.8 \pm 5.9 \text { to } \\
32.7 \pm 5.4 \mathrm{ml} / \mathrm{min} / \mathrm{kg} \text { ). }\end{array}$ & & \\
\hline $\begin{array}{l}\text { Sial et al. } \\
\text { (1998) [46] }\end{array}$ & $74 \pm 2$ & $\begin{array}{l}\text { CET70 to } 85 \% \mathrm{HR}_{\max } 30 \text { to } \\
45 \mathrm{~min} / \mathrm{session} 3 \text { to } 5 \\
\text { sessions/week, } 16 \text { weeks }\end{array}$ & $\begin{array}{l}\uparrow \text { in the } V O_{2 \max } \text { (from } 1.5 \pm 0.2 \text { to } 1.8 \\
\pm 0.3 \mathrm{l} / \mathrm{min} \text { ). }\end{array}$ & & \\
\hline $\begin{array}{l}\text { Pichot et } \\
\text { al. (2005) } \\
{[47]}\end{array}$ & $\begin{array}{l}73.5 \\
\pm 4.2\end{array}$ & $\begin{array}{l}\text { CET9*4 min } 65 \% \mathrm{HR}_{\max } \\
9^{*} 1 \mathrm{~min} 85 \% \mathrm{HR} \text { max } 45 \mathrm{~min} / \\
\text { session } 4 \text { sessions/week, } 14 \\
\text { weeks }\end{array}$ & $\begin{array}{l}\uparrow \text { in the } V_{2 \max } \text { (from } 26.8 \pm 4.4 \text { to } \\
31.8 \pm 5.1 \mathrm{ml} / \mathrm{min} / \mathrm{kg} \text { ). }\end{array}$ & $\leftrightarrow$ in SBP and DBP. & \\
\hline $\begin{array}{l}\text { Bell et al. } \\
\text { (2001) [48] }\end{array}$ & $77 \pm 7$ & $\begin{array}{l}\text { CET75 to } 85 \% \\
\text { VO }_{2 \max } 40 \mathrm{~min} / \mathrm{session} 4 \\
\text { sessions/week, } 9 \text { weeks }\end{array}$ & $\begin{array}{l}\uparrow \text { in the } \mathrm{VO}_{2 \max }(1.05 \pm 0.17 \mathrm{l} / \mathrm{min} \text { to } \\
1.22 \pm 0.22 \mathrm{l} / \mathrm{min}) \text { in trained leg. } \leftrightarrow \text { in } \\
\text { untrained leg. }\end{array}$ & & \\
\hline $\begin{array}{l}\text { Nickel et } \\
\text { al. (2011) } \\
{[36]}\end{array}$ & $71 \pm 7$ & $\begin{array}{l}\text { CET50 \% of HRR30 min/ } \\
\text { session1 session/day, } 1 \text { day }\end{array}$ & & $\begin{array}{l}\downarrow \text { in the SBP, } 15 \mathrm{~min} \text { after exercise compared to the } \\
\text { non-exercise day ( } 121 \pm 12 \mathrm{vs} .131 \pm 16 \mathrm{mmHg} ; p< \\
0.05) . \downarrow \text { in the DBP, } 24 \mathrm{~h} \text { after exercise compared to } \\
\text { the non-exercise day ( } 72 \pm 8 \text { vs. } 69 \pm 7 \mathrm{mmHg} ; p< \\
0.05 \text { ). }\end{array}$ & \\
\hline $\begin{array}{l}\text { Schocken } \\
\text { et al. } \\
\text { (1983) [49] }\end{array}$ & 72 & $\begin{array}{l}\text { CET70 to } 85 \% \mathrm{HR}_{\max } 25 \text { to } \\
30 \mathrm{~min} / \mathrm{sessionweek} / \text { week, } \\
12 \text { weeks }\end{array}$ & & $\leftrightarrow$ in SBP and DBP after training program. & $\begin{array}{l}\uparrow \text { in the maximum work load (from } 690 \pm 151 \text { to } \\
758 \pm 141 \mathrm{Kpm} / \mathrm{min} \text { ). }\end{array}$ \\
\hline $\begin{array}{l}\text { Finucane } \\
\text { et al. } \\
\text { (2010) [37] }\end{array}$ & 71.4 & $\begin{array}{l}\text { CET50 to } 70 \% \mathrm{P}_{\max } 60 \mathrm{~min} / \\
\text { sessionweek/week, } 12 \text { weeks }\end{array}$ & & $\leftrightarrow$ in SBP and DBP in training and control group. & $\begin{array}{l}\uparrow \text { in the maximum work load (from } 143.9 \pm 48.9 \text { to } \\
167.7 \pm 49.7 \mathrm{~W} \text { ) } \leftrightarrow \text { in control group. }\end{array}$ \\
\hline $\begin{array}{l}\text { Morris et } \\
\text { al. (2003) } \\
{[38]}\end{array}$ & $\begin{array}{l}70.4 \\
\pm 1.2\end{array}$ & $\begin{array}{l}\text { CET50 and } 70 \% \text { of } \\
\mathrm{VO}_{2 \max } 60 \mathrm{~min} / \mathrm{session} 1 \\
\text { sessions/week, } 8 \text { weeks }\end{array}$ & & & $\begin{array}{l}\downarrow \text { in HR and oxygen uptake after IEx compared to } \\
\text { CEx at the same relative intensity }(p<0.01) \text {. }\end{array}$ \\
\hline
\end{tabular}

CET cycle ergometer training, $V O_{2 \max }$ maximum volume of oxygen, $V T_{1}$ first ventilatory threshold, $M T P$ maximal tolerated power, $H R$ heart rate, $H R R$ heart rate reserve, $V T_{2}$ second ventilatory threshold, $R P E$ rate of perceived effort, $\mathrm{VO}_{2} 10$ oxygen consumption of $10 \mathrm{ml} / \mathrm{kg} / \mathrm{min}, P_{\max }$ maximal workload, SBP systolic blood pressure, DBP systolic blood pressure, IEx intermittent exercise, CEx continuous exercise, $\uparrow$ significant improvement within group, $\downarrow$ significant decrease within group, $\leftrightarrow$ no change within group 
Table 2 Summary of studies that analyze the effects of cycle ergometer training on metabolic outcomes

\begin{tabular}{|c|c|c|c|c|c|}
\hline \multirow[b]{3}{*}{$\begin{array}{l}\text { Author, } \\
\text { year }\end{array}$} & \multirow[b]{3}{*}{$\begin{array}{l}\text { Mean } \\
\text { age } \\
\text { (years) }\end{array}$} & \multirow[b]{3}{*}{ Protocol type } & \multicolumn{3}{|l|}{ Outcomes } \\
\hline & & & \multicolumn{3}{|l|}{ Metabolic outcomes } \\
\hline & & & Body composition & Metabolic disorders & Endocrine function \\
\hline $\begin{array}{l}\text { Lovell et } \\
\text { al. (2010) } \\
{[27]}\end{array}$ & $\begin{array}{l}75.2 \\
\pm 0.8\end{array}$ & $\begin{array}{l}\text { CET50-70\% of } \\
\text { VO }_{2 m a x} 30-45 \text { min/ } \\
\text { session3 sessions/ } \\
\text { week, } 16 \text { weeks }\end{array}$ & $\begin{array}{l}\text { Training group: } \downarrow \text { in body mass (from } 78 \pm 4.1 \text { to } 76 \\
\pm 4.2 \mathrm{~kg} \text { ). } \downarrow \text { in } \% \text { of body fat (from } 29.2 \pm 1 \text { to } 27.7 \pm \\
1 \% \text { ). in fat-free mass. } \leftrightarrow \text { in Control group. }\end{array}$ & & \\
\hline $\begin{array}{l}\text { Finucane } \\
\text { et al. } \\
\text { (2010) } \\
{[37]}\end{array}$ & 71.4 & $\begin{array}{l}\text { CET50 to } 70 \% \\
\mathrm{P}_{\max 60 \mathrm{~min} /} \\
\text { session3 sessions/ } \\
\text { week, } 12 \text { weeks }\end{array}$ & $\begin{array}{l}\text { Training group: } \downarrow \text { in weight loss }(77.2 \pm 16.1 \text { to } 77.0 \\
\pm 16.2 \mathrm{~kg}) . \downarrow \text { in BMl }\left(27.4 \pm 4.9 \text { to } 27.3 \pm 4.8 \mathrm{~kg} / \mathrm{m}^{2}\right) . \downarrow \\
\text { in waist circumference }(98.6 \pm 14.2 \text { to } 97.8 \pm \\
13.8 \mathrm{~cm}) . \downarrow \text { in intrahepatic lipid }(3.7 \pm 1.8 \text { to } 2.4 \pm \\
1.0 \%) \leftrightarrow \text { in fat-free mass. } \leftrightarrow \text { in Control group. }\end{array}$ & $\begin{array}{l}\downarrow \text { in fasting glucose, oral glucose insulin sensitivity } \\
\text { and HbA1c in both groups. }\end{array}$ & \\
\hline $\begin{array}{l}\text { Harber et } \\
\text { al. (2009) } \\
\text { [40] }\end{array}$ & 71.1 & $\begin{array}{l}\text { CET60 \% of } P_{\max } 20 \\
\text { to } 40 \mathrm{~min} / \text { session3 } \\
\text { sessions/week, } 12 \\
\text { weeks }\end{array}$ & $\begin{array}{l}\downarrow \text { in fat mass (from } 27.6 \pm 4.3 \text { to } 26.4 \pm 4.1 \mathrm{~kg} \text { ). } \downarrow \text { in } \% \\
\text { of body fat (from } 40.7 \pm 3.439 .8 \pm 3.5 \% \text { ). } \uparrow \text { in fat-free } \\
\text { mass (from } 39.2 \pm 1.4 \text { to } 39.6 \pm 1.4 \mathrm{~kg} \text { ). in body } \\
\text { weight and BMl. }\end{array}$ & & \\
\hline $\begin{array}{l}\text { Coker et } \\
\text { al. (2006) } \\
{[33]}\end{array}$ & $74 \pm 1$ & $\begin{array}{l}\text { CET50 or } 75 \% \text { of } \\
\text { VO } \mathrm{V}_{2 \max } 40 \mathrm{~min} / \\
\text { session } 4 \text { to } 5 \\
\text { sessions/week, } 12 \\
\text { weeks }\end{array}$ & $\begin{array}{l}\leftrightarrow \text { in body weight and in \% of body in } \mathrm{Ml} \text { and } \mathrm{HI} \\
\text { groups. }\end{array}$ & $\begin{array}{l}\uparrow \text { in ISGD }(5.0 \pm 0.6 \text { to } 6.4 \pm 0.5 \mathrm{mg} / \mathrm{kg} \mathrm{FFM} / \mathrm{min}) \text { in } \mathrm{HI} \\
\text { group. } \leftrightarrow \text { in Ml group. } \uparrow \text { in non-oxidative glucose } \\
\text { disposal in } \mathrm{HI} \text { group ( } 4.6 \pm 0.6 \text { to } 6.0 \pm 0.8 \mathrm{mg} / \mathrm{kg} \\
\mathrm{FFM} / \mathrm{min}) \leftrightarrow \text { in } \mathrm{Ml} \text { group. }\end{array}$ & \\
\hline $\begin{array}{l}\text { Coker et } \\
\text { al. (2009) } \\
{[34]}\end{array}$ & $71 \pm 1$ & $\begin{array}{l}\text { CET50 or } 75 \% \text { of } \\
\text { VO } \mathrm{O}_{2 \max } 40 \mathrm{~min} / \\
\text { session } 4 \text { to } 5 \\
\text { sessions/week, } 12 \\
\text { weeks }\end{array}$ & $\begin{array}{l}\leftrightarrow \text { in body weight, } \mathrm{BMI} \text {, and \% of fat in } \mathrm{Ml} \text { and } \mathrm{HI} \\
\text { groups. }\end{array}$ & $\leftrightarrow$ in plasma adiponectin in $\mathrm{Ml}$ and $\mathrm{HI}$ groups. & \\
\hline $\begin{array}{l}\text { Lovell et } \\
\text { al. (2012) } \\
\text { [29] }\end{array}$ & $\begin{array}{l}75.2 \\
\pm 3.0\end{array}$ & $\begin{array}{l}\text { CET50 to } 70 \% \\
\text { VO } 2 \text { max } 30 \text { to } \\
45 \mathrm{~min} / \mathrm{session} 3 \\
\text { sessions/week, } 16 \\
\text { weeks }\end{array}$ & & & $\begin{array}{l}\text { Training group: } \uparrow \text { in the testosterone }(16.9 \pm 1.5 \\
\text { to } 19.3 \pm 1.8 \mathrm{nmol} / \mathrm{L}) . \uparrow \text { in } \mathrm{FT} \text { concentration }(58.3 \\
\pm 4.9 \text { to } 67.2 \pm 5.7 \mathrm{pmol} / \mathrm{L}) . \leftrightarrow \text { in } \mathrm{GH} \text {, IGF- } 1 \text { and } \\
\text { SHBG concentration. } \leftrightarrow \text { in control group. }\end{array}$ \\
\hline $\begin{array}{l}\text { Sial et al. } \\
(1998) \\
{[46]}\end{array}$ & $74 \pm 2$ & $\begin{array}{l}\text { CET70 to } 85 \% \\
H R_{\text {max }} 30 \text { to } \\
45 \mathrm{~min} / \text { session3 to } \\
5 \text { sessions/week, } 16 \\
\text { weeks }\end{array}$ & $\uparrow$ in fat free mass (from $49.4 \pm 4.1$ to $50.4 \pm 4.6 \mathrm{~kg}$ ). & $\begin{array}{l}\uparrow \text { in the average rate of fat oxidation (from } 1.6 \pm 17 \\
\text { to } 2.21 \pm 28 \mu \mathrm{mol} / \mathrm{min} \text { ). } \downarrow \text { in the average rate of } \\
\text { carbohydrate oxidation (from } 3.9 \pm 483 \text { to } 3.2 \pm \\
461 \mu \mathrm{mol} / \mathrm{min} \text { ). } \downarrow \text { in the glucose Ra (from } 1.1 \pm 69 \text { to } \\
1.0 \pm 95 \mu \mathrm{mol} / \mathrm{min} \text { ). } \leftrightarrow \text { in Ra and FFA rate of } \\
\text { disappearance during exercise. }\end{array}$ & \\
\hline $\begin{array}{l}\text { Zmuda } \\
\text { et al. }\end{array}$ & $70 \pm 4$ & $\begin{array}{l}\text { CET50 to } 80 \% \\
\text { HRR60 min/ }\end{array}$ & & & $\begin{array}{l}\uparrow \text { in the serum testosterone, SHBG and total } \\
\text { serum protein }(39 \%, 19 \% \text {, and } 13 \% \text {, }\end{array}$ \\
\hline
\end{tabular}


Table 2 Summary of studies that analyze the effects of cycle ergometer training on metabolic outcomes (Continued) (1996) session1 session/

day, 1 day

respectively: $p<0.01$ ) $\uparrow$ in the FT (from $0.1 \pm 0.04$

[50]

CET40 to $100 \%$ of $\leftrightarrow$ in body weight and fat mass.

to $0.2 \pm 0.04) \leftrightarrow$ in the $L H$ concentrations.

$\begin{array}{lll}\text { Perini et } & 73.9 & \text { CET40 to } 100 \% \\ \text { al. (2002) } & +3.5 & \text { P }\end{array}$

[41]_ session3 sessions/ week, 8 weeks

CET cycle ergometer training, $V O_{2 \max }$ maximum volume of oxygen, $P_{\max }$ maximal workload, HRR heart rate reserve, $B M I$ body mass index, $M I$ moderate intensity, $H I$ high intensity, ISGD insulin-stimulated glucose disposal, $F T$ free testosterone, GH growth hormone, IGF-1 insulin like growth factor-1, SHBG sex hormone-binding globulin, LH luteinizing hormone, $R_{a}$ glycerol rate of appearance, FFA free fatty acid, $\uparrow$ significan improvement within group, $\downarrow$ significant decrease within group, $\leftrightarrow$ no change within group 
Table 3 Summary of studies that analyze the effects of cycle ergometer training on functional status

\begin{tabular}{|c|c|c|c|c|}
\hline \multirow[b]{3}{*}{$\begin{array}{l}\text { Author, } \\
\text { year }\end{array}$} & \multirow[b]{3}{*}{$\begin{array}{l}\text { Mean } \\
\text { age } \\
\text { (years) }\end{array}$} & \multirow[b]{3}{*}{ Protocol type } & \multicolumn{2}{|l|}{ Outcomes } \\
\hline & & & \multicolumn{2}{|l|}{ Functional status } \\
\hline & & & Muscle strength & Physical performance \\
\hline $\begin{array}{l}\text { Lovell et } \\
\text { al. (2010) } \\
{[27]}\end{array}$ & $\begin{array}{l}75.2 \pm \\
0.8\end{array}$ & $\begin{array}{l}\mathrm{CET} 50-70 \% \text { of } \mathrm{VO}_{2 \max } 30- \\
45 \mathrm{~min} / \mathrm{session3} \text { sessions/ } \\
\text { week, } 16 \text { weeks }\end{array}$ & $\begin{array}{l}\uparrow \text { in leg strength (from } 45.8 \pm 7.9 \text { to } 54.0 \pm 8.0 \mathrm{~kg} \text { ). } \uparrow \text { in peak power (from } \\
144 \pm 5 \text { to } 168 \pm 6 \mathrm{~W} \text { ) } \uparrow \text { in upper leg muscle mass (from } 10.2 \pm 5.3 \text { to } 11.0 \\
\pm 5.4 \mathrm{~kg} \text { ). } \uparrow \text { in total-leg muscle mass (from } 12.04 \pm 4.8 \text { to } 12.9 \pm 5.1 \mathrm{~kg} \text { ). }\end{array}$ & \\
\hline $\begin{array}{l}\text { Lovell et } \\
\text { al. (2012) } \\
{[29]}\end{array}$ & $\begin{array}{l}75.2 \pm \\
3.0\end{array}$ & $\begin{array}{l}\text { CET50 to } 70 \% \mathrm{VO}_{2 \max } 30 \\
\text { to } 45 \mathrm{~min} / \mathrm{session3} \\
\text { sessions/week, } 16 \text { weeks }\end{array}$ & $\begin{array}{l}\uparrow \text { in peak power }(148 \pm 5 \text { to } 168 \pm 6 \mathrm{~W}) . \uparrow \text { in leg strength }(45.8 \pm 7.3 \text { to } \\
54.0 \pm 8.0 \mathrm{~kg}) .\end{array}$ & \\
\hline $\begin{array}{l}\text { Harber et } \\
\text { al. (2009) } \\
{[40]}\end{array}$ & 71.1 & $\begin{array}{l}\text { CET } 60 \% \text { of } \mathrm{P}_{\max } 20 \text { to } \\
40 \mathrm{~min} / \text { session3 sessions/ } \\
\text { week, } 12 \text { weeks }\end{array}$ & $\begin{array}{l}\uparrow \text { in the quadriceps muscle volume (from } 587 \pm 55 \text { to } 654 \pm 60 \mathrm{~cm}^{3} \text { ). } \uparrow \text { in } \\
\left.\text { the knee extensor power (from } 199 \pm 25 \text { to } 261 \pm 27 \mathrm{~cm}^{3}\right) . \uparrow \text { in normalized } \\
\left.\text { power (from } 5.8 \pm 0.8 \text { to } 6.5 \pm 0.8 \mathrm{~W} / \mathrm{cm}^{2}\right) . \uparrow \text { in the knee extensor power } \\
\text { (from } 4.9 \pm 0.4 \text { to } 5.9 \pm 0.5 \mathrm{Nm} / \mathrm{cm}^{2} \text { ). }\end{array}$ & \\
\hline $\begin{array}{l}\text { Buchner } \\
\text { et al. } \\
\text { (2009) [30] }\end{array}$ & 75 & $\begin{array}{l}\text { CET75 \% of HRR30 to } \\
35 \mathrm{~min} / \mathrm{session} 3 \text { sessions/ } \\
\text { week, } 24 \text { to } 26 \text { weeks }\end{array}$ & $\begin{array}{l}\uparrow \text { in strength at the knee extension (from } 88 \pm 30 \text { to } 97 \pm 13 \mathrm{Nm} \text { ) } \leftrightarrow \text { in } \\
\text { the strength of the other muscles. }\end{array}$ & $\leftrightarrow$ in gait and balance test. \\
\hline $\begin{array}{l}\text { Perini et } \\
\text { al. (2002) } \\
{[41]}\end{array}$ & $\begin{array}{l}73.9 \pm \\
3.5\end{array}$ & $\begin{array}{l}\text { CET } 40 \text { to } 100 \% \text { of } \\
P_{\max 60 \mathrm{~min} / \mathrm{session} 3} \\
\text { sessions/week, } 8 \text { weeks }\end{array}$ & $\begin{array}{l}\leftrightarrow \text { in the maximal isometric quadriceps muscle strength, and the maximal } \\
\text { isometric quadriceps endurance. }\end{array}$ & \\
\hline $\begin{array}{l}\text { Denison } \\
\text { et al. } \\
\text { (2013) }\end{array}$ & 71.4 & $\begin{array}{l}\text { CET50 to } 70 \% \\
\text { HR } 6 \text { max } 60 \text { min/session3 } \\
\text { sessions/week, } 12 \text { weeks }\end{array}$ & $\leftrightarrow$ in maximum grip strength in training and control groups. & $\begin{array}{l}\text { Training group: } \downarrow \text { in the } 6 \mathrm{~m} \text { TUG performance (from } 11.0 \pm 2.0 \text { to } 10.2 \pm \\
1.6 \mathrm{~s} \text { ) in the training group compared to control group. } \leftrightarrow \text { in } 3 \mathrm{~m} \text { walk, } \\
\text { one-legged balance and chair rise. } \leftrightarrow \text { in control group. }\end{array}$ \\
\hline $\begin{array}{l}\text { Malbut et } \\
\text { al. (2002) } \\
\text { [32] }\end{array}$ & $\begin{array}{l}81 \pm \\
2.28\end{array}$ & $\begin{array}{l}\text { CET13-15 of RPE13 to } \\
20 \mathrm{~min} / \mathrm{session} 3 \text { to } 6 \\
\text { sessions/week, } 24 \text { weeks }\end{array}$ & $\begin{array}{l}\leftrightarrow \text { in isometric knee extensor strength, isometric elbow flexor strength } \\
\text { and lower limb extensor power. }\end{array}$ & \\
\hline $\begin{array}{l}\text { Mangione } \\
\text { et al. } \\
\text { (1999) [35] }\end{array}$ & $\begin{array}{l}71 \pm \\
6.9\end{array}$ & $\begin{array}{l}\text { CET40 or } 70 \% \\
\text { HRR25 min/session3 } \\
\text { sessions/week, } 10 \text { week }\end{array}$ & & $\begin{array}{l}\downarrow \text { in the chair rise time (from } 23.3 \pm 9.1 \text { to } 19.1 \pm 6.6 \text { s). } \uparrow \text { in the } 6 \text {-min walk } \\
\text { test (from } 489.6 \pm 109.1 \text { to } 533.8 \pm 105.0 \mathrm{~m} \text { ). }\end{array}$ \\
\hline
\end{tabular}

CET cycle ergometer training, $V_{2}$ max maximum volume of oxygen, $P_{\max }$ maximal workload, $H R_{\max }$ maximal heart rate, $R P E$ rate of perceived effort, $H R R$ heart rate reserve, TUG Timed Up and Go test, $\uparrow$ significant improvement within group, $\downarrow$ significant decrease within group, $\leftrightarrow$ no change within group 
Table 4 Summary of study that analyze the effects of cycle ergometer training on cognition function

\begin{tabular}{|c|c|c|c|}
\hline & & & Outcomes \\
\hline Author, year & $\begin{array}{l}\text { Mean } \\
\text { age } \\
\text { (years) }\end{array}$ & Protocol type & Cognition function \\
\hline $\begin{array}{l}\text { Palleschi et al. } \\
\text { (1996) [39] }\end{array}$ & $74.0 \pm 1.5$ & $\begin{array}{l}\mathrm{CET70} \% \text { of } \mathrm{HR}_{\max } 20 \mathrm{~min} / \text { session } 3 \\
\text { sessions/week, } 3 \text { months }\end{array}$ & $\begin{array}{l}\uparrow \text { in the test of attentional matrix }(35.9 \pm 3.8 \text { to } 43.9 \pm 6.3) . \uparrow \text { in the verbal span test } \\
(2.8 \pm 0.6 \text { to } 3.8 \pm 0.6) . \uparrow \text { in the supraverbal span test }(7.4 \pm 0.9 \text { to } 12.6 \pm 2.6) . \uparrow \text { in the } \\
\text { MMSEP }(19.4 \pm 1.1 \text { to } 21.7 \pm 1.3) \text {. }\end{array}$ \\
\hline
\end{tabular}

CET cycle ergometer training, $H R_{\max }$ maximal heart rate, MMSEP mini mental state examination, ? significant improvement within group

group $(121 \pm 12$ vs. $131 \pm 16 \mathrm{mmHg} ; p<0.05)$ and $(72 \pm 8$ vs. $69 \pm 7 \mathrm{mmHg} ; p<0.05)$, respectively. In a small pilot study including 15 older subjects, Perini et al. [41] observed a significant reduction in resting systolic (16 and $14 \%, p=0.001$ ) and diastolic blood pressure (13 and $11 \%, p=0.004$ ) in older men and women respectively, with no significant effects on SBP and DBP on recovery after 8 weeks of CET. However, three other studies [37, 47,49 ] did not observe any significant change in SBP and DBP following CET.

Based on these studies, short-term CET seems to be associated in some extent with a significant decrease in SBP by $8-16 \%$ and in DBP by $4-13 \%$ in older adults over 70 . This can be associated with a decrease in cardiac morbidity, stroke, and all-cause mortality.

\section{Effects on endurance parameters}

In this review, eight studies have shown that CET leads to significant improvement in endurance parameters of older adults over 70 [28, 31, 32, 37, 38, 42, 43, 49] (Table 1). Vogel et al. [28] reported a significant increase in the first ventilatory threshold $\left(\mathrm{VT}_{1}\right)$ by 27.9 and $21.2 \%$ (all, $p<$ $0.05)$, respectively, in older men and women. Likewise, these authors reported a significant decrease in the heart rate $(\mathrm{HR})$ at pre-training $\mathrm{VT}_{1}(-6.2$ and $-5.2 \%$, respectively; $p<0.05)$ as well as in lactate concentrations at pretraining maximal tolerated power (MTP) (-23.4 and $-20 \%$, respectively; $p<0.05$ ), after nine weeks of CET. In a small group of older people, Morris et al. [38] reported that at the same relative intensity $(50 \%$ or $70 \%$ of $\mathrm{VO}_{2 \max }$ ), interval exercise training resulted in a significant reduction in HR and oxygen uptake as opposed to continuous exercise training $(p<0.01)$. In a small group of older adults (72 \pm 4.4 years old), Babcock et al. [31] reported a $21 \%(p<0.05)$ increase in oxygen uptake $\left(\mathrm{VO}_{2}\right)$ at $\mathrm{VT}_{1}$. However, they did not report any significant change in $\mathrm{HR}$ at $\mathrm{VT}_{1}$ after 72 exercise sessions of CET. In another study in older men and women, Malbut et al. [32] reported a significant decrease in $\mathrm{HR}$ at $\mathrm{VO}_{2} 10$ (heart rate at an oxygen consumption of $10 \mathrm{ml} / \mathrm{kg} / \mathrm{min})$ by $8 \%(p<$ $0.05)$ and $15 \%(p<0.01)$ respectively, after 24 weeks of CET. Temfemo et al. [43] reported a significant increase in $\mathrm{VT}_{1}(17 \%, p<0.05)$ in older patients after 8 weeks of CET at $\mathrm{VT}_{1}$. Finally, Schocken et al. [49], Haber et al. [42] and Finucane et al. [37] reported significant $10 \%(p<$
$0.008), 16$ and $16.5 \%(p<0.01)$ respective increases in the maximum workload, after 12 weeks of CET among older patients.

Based on these studies, short to medium-term of CET at an intensity of $\mathrm{VT}_{1}$ appears to be an optimal way of improving endurance parameters among older adults over 70 , specifically through an increase in the oxygen uptake by $21 \%$, in the mean $\mathrm{VT}_{1}$ and maximum workload by 22 and $14 \%$, respectively. These improvements are important for seniors, and may contribute towards a better quality of life.

\section{Effects on metabolic outcomes Effects on body composition}

In this review, the effects of CET on body composition in older patients over 70 were evaluated in eight studies [27, 33, 34, 37, 40, 41, 46, 51] (Table 2). Specifically, a 16-week CET program at $50-70 \%$ of $\mathrm{VO}_{2 \max }$ resulted in a significant decrease in body mass and in the percentage of body fat $(-2.6$ and $-5 \%$ respectively; $p<0.05)$, with no significant change in fat-free mass in older patients [27]. In 100 healthy older adults, Finucane et al. [37] reported a significant decrease in total body mass $(-10 \%, p=0.007)$, BMI $(-0.4 \%, p=0.03)$, in waist circumference $(-0.8 \%, p=$ $0.02)$ and in intrahepatic lipids $(-54 \%, p=0.024)$ in the exercise group compared with controls, whereas the same authors reported no significant alteration in fat mass and fat-free mass in the two groups after 12 weeks at 50-70\% of maximum power $\left(\mathrm{P}_{\max }\right)$ of CET. However, there is evidence that the aforementioned exercise-induced adaptations can also occur independently of weight loss [51]. For example, Harber et al. [40] reported a significant decrease in fat mass $(-3.9 \%, p<0.01)$ and in percentage body fat $(-2.4 \%, p<0.01)$ with a significant increase in fat-free mass $(-0.9 \%, p<0.01)$, without an overall decrease in body weight following 12-week of CET at $60 \%$ of $\mathrm{P}_{\max }$. Likewise, 16 weeks of CET at 70-85\% of $\mathrm{HR}_{\max }$ in older patients improved fat-free mass by $2 \%(p<0.05)$ without an overall decrease in body weight [46]. Conversely, three studies reported no significant change in body composition after 12 weeks of CET [33, 34, 41].

These outcomes suggest that 12-16 weeks of moderate to high intensity of CET may be an appropriate way to improve the body composition among older adults over 70 , specifically by a significant decrease in the mean 
percentage of body fat and of body mass by 3.7 and $6.3 \%$ respectively, and particularly by maintaining freefat mass. These data highlighted the importance of CET when designing weight management strategies among older patients over 70 .

\section{Effects on metabolic disorders}

Specific effects of CET on metabolic disorders were reported in 4 studies [33, 34, 37, 46] (Table 2). Indeed, Sial et al. [46] observed after 16 weeks of CET, a significant increase in the average rate of fat oxidation during exercise $(33 \%, p=0.002)$, and a significant decrease in the average rate of carbohydrate oxidation during exercise $(-19 \%, p=0.003)$. However, these authors did not report any significant change in the glycerol rate of appearance ( $\mathrm{Ra}$ ) and in the free fatty acid (FFA) rate of disappearance during exercise, but did report a significant $11 \%$ decrease in glucose $\mathrm{R}_{\mathrm{a}}$ after the training program $(p=0.01)$ among older adults. Further, 12 weeks of CET 4-5 times per week (40 min per session) led to a significant increase in insulin-stimulated glucose disposal (ISGD) $(28 \%, p<0.05)$ as well as in nonoxidative glucose disposal (NOGD) $(30 \%, p<0.05)$ only in a high-intensity (HI) training group, with no significant change in the moderate-intensity (MI) training group [33].

In another study, 12 weeks of CET led to a slight (non-significant) increase in plasma adiponectin in both MI and HI training groups [34]. Conversely, Finucane et al. [37] reported no differences in fasting glucose, oral glucose insulin sensitivity and HbA1c between the training and control groups after 12 weeks of CET.

According to the above studies, short-term of CET can be in some extent an efficient strategy to prevent the metabolic disorders among older adults over 70, specifically through an increase in the fat oxidation and a decrease in the carbohydrate metabolism during exercise as well as by enhancing overall glucose disposal which have a positive effect on the regulation of glucose metabolism. This could have important clinical implications by increasing exercise capacity in this population.

\section{Effects on endocrine function}

Only two of the studies reviewed analyzed the effects of CET on endocrine function in older patients $[29,50]$ (Table 2). Zmuda et al. [50] reported a significant increase in serum testosterone, sex hormone-binding globulin (SHBG), total serum protein and the free testosterone index $(39,19,13$ and $23 \%$ respectively; all $p<0.01)$ with no significant change in LH concentrations, during 60 min of CET at $50-80 \%$ of HRR. After 48 sessions of CET, Lovell et al. [29] observed a significant $14 \%$ increase in plasma concentration of testosterone, and of $15 \%$ in free testosterone concentration (all, $p<0.05$ ), with no significant change in growth hormone $(\mathrm{GH})$, insulin like growth factor-1 (IGF-1) or in SHBG concentration.

According to these two reports, CET can have significant effects on the major male reproductive hormone, mainly through an improvement in the concentration of testosterone in plasma, which, in turn, may have cardiovascular protective effects in older adults over 70 .

\section{Effects on functional status \\ Effects on muscle strength}

This review shows that CET may be a sufficient stimulus to increase muscle strength and power in older patients over 70 through seven studies [27, 29, 30, 32, 40, 41] (Table 3). For example, after 48 sessions of CET at 50-70\% of $\mathrm{VO}_{2 \max }(30-45 \mathrm{~min} / \mathrm{session})$, Lovell et al. [27] reported a significant increase in multiple muscle strength outcomes in older adults (i.e., leg strength (18\%), leg power (12\%), upper leg muscle mass (7\%), and total leg muscle mass (7\%), all $p<0.05)$. Similarly, Lovell et al. [29] observed a significant $18 \%(p<0.05)$ increase in leg strength and a $13.5 \%(p<0.05)$ increase in peak power after 16 weeks of CET in older patients. A 12-week exercise program (cycling 3-4 times/week, 20-45 min/session at 60-80 \% of HRR) led to an $11 \%$ improvement in quadriceps muscle volume, a $23 \%$ increase in knee extensor power and a $31 \%$ increase in knee extensor peak isometric force, as well as a $12 \%$ increase in normalized power and a $20 \%$ increase in normalized force (all, $p<0.05$ ) [40]. Nine months of CET three times per week ( 35 min per session) increased the strength of the knee extensor by $10 \%(p<0.05)$, with no significant change in the strength of the other muscles [30]. Conversely, Perini et al. [41] did not report any significant change in quadriceps isometric strength or endurance after 8 weeks of CET. Likewise, Denison et al. reported no significant change between training and control groups in maximum grip strength after 12 weeks of CET at 50-70 of $\mathrm{HR}_{\text {max }}$. Finally, Malbut et al. [32] observed no effect of CET in isometric knee extensor strength, isometric elbow flexor strength or lower limb extensor power among older patients.

To summarize the above data, CET for 20-45 min, three times a week for 12-16 weeks at 50-70\% of $\mathrm{VO}_{2 \max }$, is an efficient way of maintaining and improving muscle strength among older adults over 70, specifically through the development of leg and knee extension strength as well as the strength of the upper and total leg muscle mass.

\section{Physical performance}

Conflicting results have been reported concerning the effect of CET on the physical performance of older patients over 70 [30, 35] (Table 3). In a randomized controlled trial, Buchner et al. [30] did not observe any significant improvement in gait and balance test, after 24 weeks of CET. 
Denison et al., reported only a significant decrease in the $6 \mathrm{~m}$ timed up and go test (TUG) by $7 \%(p=0.04)$ in the training group compared to the control group, with no significant differences between groups in $3 \mathrm{~m}$ walk, eyes closed one-legged balance, and chair rise test after 12week of CET. In contrast, ten weeks of CET led to a significant improvement in chair rise time $(-22 \%, p<0.001)$ and in the 6-minute walk test $(9 \%, p<0.001)$ among older frail adults [35].

According to these three reports, short to medium-term CET modestly improve physical performance of older patients over 70 , specifically through a decrease in the TUG as well as in chair raise time and an increase in the 6minute walk test. Nevertheless, further studies are needed to investigate the effects of long-term CET on the physical performance of this aged population.

\section{Effect on cognitive function}

To our knowledge, only one study has shown that CET can help improve cognition in frail older adults over 70 (Table 4). Indeed, Palleschi et al. [39] reported a significant improvement in cognitive performance, in particular an increase in the test of attentional matrix, the verbal span test, the supraverbal span test and the mini mental state examination (22, 34, 71 and $12 \%$ respectively; $p<0.0001)$, after 3 months of CET in a small group of older patients affected by Alzheimer's senile dementia.

According to the outcomes of this study, CET could be promoted in older adults as a cost-effective, efficient, and viable way to reduce cognitive dysfunction, but further studies are needed to confirm these finding among older patients over 70 .

\section{Discussion}

\section{Principal findings}

To our knowledge this is the first systematic review targeting the beneficial effects of cycle ergometer training (CET) on the health of older adults over 70.

According to the current evidence we suggest that CET is a suitable form of endurance training for promoting overall physical health among older adults over 70, particularly because it is relatively easy and safe and causes no related injuries. Further, as the upper body is less in motion in bicycle ergometer training than when the individual is walking on a treadmill, it is easier to record the vital signs and to collect blood samples especially for older frail individuals.

Overall, this systematic review included 25 published studies: 12 randomized studies and 13 non-randomized studies that analyzed the effect of CET on health outcomes among older adults over 70 .

These studies suggest that CET has a positive impact on cardiovascular function through an improvement in cardiorespiratory fitness, blood pressure values and endurance parameters in older individuals over 70. Specifically, it helps control metabolic outcomes through an improvement in body composition, metabolic and endocrine disorders. CET also improves functional reserve capacity mainly by increasing muscle strength, with conflicting results concerning the physical performance. Finally, one study suggests that CET may improve also the cognitive performance in older adults over 70 .

\section{Comparison with other studies}

Although several systematic reviews have already been published on the benefits of CET for the general population, to our knowledge, very few studies have focused on health benefits for older adults over 70 .

Concerning the effect of cycling on cardio-respiratory performance, functional status and metabolic outcomes, our findings are in agreement with those of a systematic review by Oja et al. [20]. These authors analyzed the health benefits of cycling in middle-aged and older people. Their findings indicated clear improvement through enhancement of cardiovascular parameters, a consistent relationship between cycling and functional status through an improvement in muscle strength and regulation of metabolic function.

Although their review illustrates the potential positive relationship between cycling and health for the general population, it was not a systematic review focusing on a group of well-defined age, and it drew on a wide range of evidence. Our review provides more details on the health benefits of CET for older adults over 70, drawing on more specific intervention studies.

Valenzuela [52] studied the effect of progressive resistance training interventions in older adults aged between 80 and 89 in nursing homes. This study reported significant improvements in muscle strength and functional performance through a progressive resistance training exercise. Despite the difference in the type of training protocol, these results are in agreement with the results of our review because they also showed an improvement functional status.

On the other hand, concerning functional status, our review disagrees with the results of a review by Giné-Garriga et al. [53], who studied the effect of exercise training on functional status in frail older adults over 65 . The authors of this review did not report any consistent effect of exercise training on functional status for older adults; this can probably be explained by the wide range of protocols they reviewed.

With increasing age, there is a well-described decline in voluntary physical activity, leading to an increased risk of frailty. In the present systematic review, we restricted the inclusion criteria to older adults aged over 70, whereas Keogh et al. [54] examined the effect of dancing in healthy older adults over 60. Despite the difference in 
the age of subjects and the type of training program, our review agrees with the results of the above review regarding the improvement in functional status and cardiorespiratory performance.

Finally, regarding functional status, our systematic review agrees with the review by Latham et al. [55], in which these authors demonstrate the beneficial effects of progressive resistance training in adults over 60 .

\section{Strengths and limitations of the review}

The main strengths of this review are the comprehensive literary search and the inclusive approach to the types of interventions examined. We searched eight literature databases across a wide range of disciplines, while imposing as few limits as possible on our search.

The strong points of our review are first, we targeted a well-defined previously neglected population of older adults over 70, and second, we revealed robust performance outcomes.

As in all risk assessments, our review has a few limitations. First, we did not include publications that were not in English; so a language bias is possible. Second, the heterogeneity of the studies and of the training protocols made it difficult to establish precise outcomes concerning the intensity, frequency and duration of exercise training across studies. Third, the age limits we chose resulted in the exclusion of a large number of articles. However, given the current challenges of providing care for an aging population, we considered it important to select information that targeted this particular frail population.

\section{Conclusion}

Overall, this systematic review of studies on the effect of CET on the health of older adults over 70 revealed four different types of outcomes, cardiovascular function, metabolic outcomes, functional status, and cognitive performance.

Cycle ergometer training is particularly appropriate for older adults over 70 thanks to its ability to improve cardiorespiratory fitness, blood pressure values and endurance parameters. Further, CET is associated in some extent with a regulation of metabolic outcomes through an improvement in body composition and the prevention of metabolic and endocrine disorders. It has a positive effect on functional status by increasing muscle strength and in some extent enhancing physical performance. In this connection, it is worth emphasizing that this form of exercise is not only safer, but puts less stress on the joints of older adults than other typical components of exercise programs. Finally, CET may improve also the cognitive performance.

Clinicians can now use this evidence to formulate actions to enable older adults over 70 to profit from the health benefits of CET. This will reinforce the current public health efforts to improve the health of older adults, and to help them to continue pursuing their daily activities independently.

\section{Competing interest}

The authors declare that there is no conflict of interest regarding the publication of this article.

\section{Authors' contributions}

WB, TV and ES made the conception and performed the design of the study. $W B, B G$ and GK made substantial contributions to the acquisition, analysis and interpretation of data. WB, ES and TV drafted and revised the article. All the authors mentioned meet the criteria for authorship and give final approval of this manuscript to be published.

\section{Acknowledgement}

We thank Dr Daphne Goodfellow and Dr Gienia Offord for their corrections of the English text. We also thank Cecile Dufour and Julien Bahlau for their assistance in data collection and analysis.

\section{Declaration of original work}

The authors declare that the submitted work has not been published before (neither in English or any other language) and that the work is not under consideration for publication elsewhere.

\section{Author details}

${ }^{1}$ Geriatric Department, University Hospital, Strasbourg, France. ${ }^{2}$ Department of Physiology and EA-3072, Faculty of Medicine, Strasbourg University, Strasbourg, France. ${ }^{3}$ Functional Explorations Department, University Hospital, Strasbourg, France.

Received: 2 October 2015 Accepted: 22 October 2015

Published online: 02 November 2015

\section{References}

1. Haskell WL, Lee IM, Powell KE, Blair SN, Franklin BA, Macera CA, et al. Physical activity and public health: updated recommendation for adults from the American College of Sports Medicine and the and the American Heart Association. Med Sci Sports Exerc. 2007;116:1081-93.

2. Stessman J, Hammerman-Rozenberg R, Cohen A, Ein-Mor E, Jacobs JM. Physical activity, function, and longevity among the very old. Arch Intern Med. 2009:169:1476-83.

3. Vogel T, Brechat PH, Leprêtre PM, Kaltenbach G, Berthel M, Lonsdorfer J. Health benefits of physical activity in older patients: a review. Int J Clin Pract. 2009;63:303-20.

4. Wen CP, Wai JP, Tsai MK, Yang YC, Cheng TY, Lee MC, et al. Minimum amount of physical activity for reduced mortality and extended life expectancy: a prospective cohort study. Lancet. 2011;378:1244-53.

5. Dogra S, Stathokostas L. Sedentary behavior and physical activity are independent predictors of successful aging in middle-aged and older adults. J Aging Res. 2012;2012:1-8.

6. Thorp AA, Owen N, Neuhaus M, Dunstan DW. Sedentary behaviors and subsequent health outcomes in adults. Am J Prev Med. 2011;41:207-15.

7. Ekelund U, Franks PW, Sharp S, Brage S, Wareham NJ. Increase in physical activity energy expenditure is associated with reduced metabolic risk independent of change in fatness and fitness. Eur Diabetes Care. 2007;30:2101-6.

8. Acree LS, Longfors J, Fjeldstad AS, Fjeldstad C, Schank B, Nickel KJ, et al. Physical activity is related to quality of life in older adults. Health Qual Life Outcomes. 2006:4:37.

9. Davis MG, Fox KR. Physical activity patterns assessed by accelerometry in older people. Eur J Appl Physiol. 2007;100:581-9.

10. American College of Sports Medicine, Chodzko-zajko WJ, Proctor DN, Fiatarone Singh MA, Minson CT, Nigg CR, et al. American College of Sports Medicine position stand. Exercise and physical activity for older adults. Med Sci Sports Exerc. 2009;41:1510-30.

11. Fleg JL. Aerobic exercise in the elderly: a key to successful aging. Discov Med. 2012;13:223-8. 
12. Lepretre PM, Vogel T, Brechat PH, Dufour S, Richard R, Kaltenbach G, et al. Impact of short-term aerobic interval training on maximal exercise in sedentary aged subjects. Int J Clin Pract. 2009;63:1472-8.

13. Cheng SP, Yang CY, Tang Fl, Chen IJ. Training effects of a 12-week walking program on Parkinson disease patients and community-dwelling older adults. NeuroRehabilitation. 2013;32:967-76.

14. Oh-Park M, Holtzer R, Mahoney J, Wang C, Verghese J. Effect of treadmill training on specific gait parameters in older adults with frailty: case series. J Geriatr Phys Ther. 2011;34:184-8.

15. Sanderson B, Askew C, Stewart I, Walker P, Gibbs H, Green S. Short-term effects of cycle and treadmill training on exercise tolerance in peripheral arterial disease. J Vasc Surg. 2006;44:119-27.

16. Ozaki H, Loenneke JP, Thiebaud RS, Abe T. Cycle training induces muscle hypertrophy and strength gain: strategies and mechanisms. Acta Physiol Hung. 2015;102:1-22

17. Bauman $A E$, Rissel C. Cycling and health: an opportunity for positive change? Med J Aust. 2009;190:347-8.

18. Pang MY, Eng JJ, Dawson AS, Gylfadóttir S. The use of aerobic exercise training in improving aerobic capacity in individuals with stroke: a meta-analysis. Clin Rehabil. 2006;20:97-111.

19. Macaluso A, Young A, Gibb KS, Rowe DA, De Vito G. Cycling as a novel approach to resistance training increases muscle strength, power, and selected functional abilities in healthy older women. J Appl Physiol. 2003;95:2544-53.

20. Oja P, Titze S, Bauman A, De Geus B, Krenn P, Reger-Nash B, et al. Health benefits of cycling: a systematic review. Scand J Med Sci Sports. 2011;21:496-509.

21. Bouillon LE, Sklenka DK, Driver AC. Comparison of training between 2 cycle ergometers on dynamic balance for middle-aged women. J Sport Rehabil. 2009;18:316-26.

22. Janssen TW, Beltman JM, Elich P, Koppe PA, Konijnenbelt H, de Haan A, et al. Effects of electric stimulation-assisted cycling training in people with chronic stroke. Arch Phys Med Rehabil. 2008;89:463-9.

23. Rissel C, Passmore E, Mason C, Merom D. Two pilot studies of the effect of bicycling on balance and Leg strength among older adults. J Environ Public Health. 2013;2013:1-6.

24. Zarins ZA, Wallis GA, Faghihnia N, Johnson ML, Fattor JA, Horning MA, et al. Effects of endurance training on cardiorespiratory fitness and substrate partitioning in postmenopausal women. Metabolism. 2009;58:1338-46.

25. Blumenthal JA, Emery CF, Madden DJ, Coleman RE, Riddle MW, Schniebolk $S$, et al. Effects of exercise training on cardiorespiratory function in men and women older than 60 years of age. Am J Cardiol. 1991;67:633-9.

26. Stemplewski R, Maciaszek J, Salamon A, Tomczak M, Osiński W. Effect of moderate physical exercise on postural control among 65-74 years old men. Arch Gerontol Geriatr. 2012;54:e279-83.

27. Lovell DI, Cuneo R, Gass GC. Can aerobic training improve muscle strength and power in older men? J Aging Phys Act. 2010;18:14-26.

28. Vogel T, Leprêtre PM, Brechat PH, Lonsdorfer E, Benetos A, Kaltenbach G, et al. Effects of a short-term personalized Intermittent Work Exercise Program (IWEP) on maximal cardio-respiratory function and endurance parameters among healthy young and older seniors. J Nutr Health Aging. 2011;15:905-11.

29. Lovell DI, Cuneo R, Wallace J, McLellan C. The hormonal response of older men to sub-maximum aerobic exercise: The effect of training and detraining. Steroids. 2012;77:413-8.

30. Buchner DM, Cress ME, De Lateur BJ, Esselman PC, Margherita AJ, Price R, et al. The effect of strength and endurance training on gait, balance, fall risk, and health services use in community-living older adults. J Gerontol A Biol Sci Med Sci. 1997;52:M218-24.

31. Babcock MA, Paterson DH, Cunningham DA. Effects of aerobic endurance training on gas exchange kinetics of older men. Med Sci Sports Exerc. 1994;26:447-52.

32. Malbut KE, Dinan S, Young A. Aerobic training in the 'oldest old': the effect of 24 weeks of training. Age Ageing. 2002;31:255-60.

33. Coker RH, Hays NP, Williams RH, Brown AD, Freeling SA, Kortebein PM, et al. Exercise-induced changes in insulin action and glycogen metabolism in elderly adults. Exercise-induced changes in insulin action and glycogen metabolism in elderly adults. Med Sci Sports Exerc. 2006;38:433-8.

34. Coker RH, Williams RH, Kortebein PM, Sullivan DH, Evans WJ. Influence of exercise intensity on abdominal Fat and adiponectin in elderly adults. Metab Syndr Relat Disord. 2009;7:363-8.
35. Mangione KK, McCully K, Gloviak A, Lefebvre I, Hofmann M, Craik R. The effects of high-intensity and Low-intensity cycle ergometry in older adults with knee osteoarthritis. J Gerontol A Biol Sci Med Sci. 1999;54:M184-90.

36. Nickel KJ, Acree LS, Gardner AW. Effects of a single bout of exercise on arterial compliance in older adults. Angiology. 2011;62:33-7.

37. Finucane FM, Sharp SJ, Purslow LR, Horton K, Horton J, Savage DB, et al. The effects of aerobic exercise on metabolic risk, insulin sensitivity and intrahepatic lipid in healthy older people from the Hertfordshire Cohort Study: a randomized controlled trial. Diabetologia. 2010;53:624-31.

38. Morris N, Gass G, Thompson M, Conforti D. Physiological responses to intermittent and continuous exercise at the same relative intensity in older men. Eur J Appl Physiol. 2003;90:620-5.

39. Palleschi L, Vetta F, De Cennaro E, Idone G, Sottosantic C, Gianni W, et al. Effect of aerobic training on the cognitive performance of elderly patients with senile dementia of Alzheimer type. Arch Gerontol Geriatr. 1996;22:47-50.

40. Harber MP, Konopka AR, Douglass MD, Minchev K, Kaminsky LA, Trappe TA, et al. Aerobic exercise training improves whole muscle and single myofiber size and function in older women. Am J Physiol Regul Integr Comp Physiol. 2009;297:R1452-9.

41. Perini R, Fisher N, Veicstenas A, Pendergast DR. Aerobic training and cardiovascular responses at rest and during exercise in older men and women. Med Sci Sports Exerc. 2002;34:700-8.

42. Haber $\mathrm{P}$, Honiger $\mathrm{B}$, Klicperai $\mathrm{M}$, Niederbergeri $\mathrm{M}$. Effects in elderly people 6776 years of age of three-month endurance training on a bicycle ergometer. Eur Heart J. 1984;5:37-9.

43. Temfemo A, Chlif M, Mandengue SH, Lelard T, Choquet D, Ahmaidi S. Is there a beneficial effect difference between age, gender, and different cardiac pathology groups of exercise training at ventilatory threshold in cardiac patients? Cardiol J. 2011;18:632-8.

44. Charifi N, Féasson L, Costes F, Denis C. Effects of endurance training on satellite cell frequency in skeletal muscle of old men. Muscle Nerve. 2003;28:87-92.

45. Charifi N, Kadi F, Féasson L, Costes F, Geyssant A, Denis C. Enhancement of microvessel tortuosity in the vastus lateralis muscle of old men in response to endurance training. J Physiol. 2004;554:559-69.

46. Sial S, Coggan AR, Hickner RC, Klein S. Training-induced alterations in fat and carbohydrate metabolism during exercise in elderly subjects. Am J Physiol. 1998;274:E785-90.

47. Pichot V, Roche F, Denis C, Garet M, Duverne D, Costes F, et al. Interval training in elderly men increases both heart rate variability and baroreflex activity. Clin Auton Res. 2005;15:107-15.

48. Bell C, Paterson DH, Kowalchuk JM, Moy AP, Thorp DB, Noble E, et al. Determinants of oxygen uptake kinetics in older humans following single-limb endurance exercise training. Exp Physiol. 2001;86:659-65

49. Schocken DD, Blumenthal JA, Port S, Hindle I, Coleman RE. Physical conditioning and left ventricular performance in the elderly: assessment by radionuclide angiocardiography. Am J Cardiol. 1983;52:359-64.

50. Zmuda JM, Thompson PD, Winters SJ. Exercise increases serum testosterone and sex hormone-binding globulin levels in older men. Metabolism. 1996:45:935-9.

51. Petros CD, Aleksandra SM, Andres EC. Exercise-induced biological and psychological changes in overweight and obese individuals: a review of recent evidence. ISRN Physiology. 2014;2014:1-11.

52. Valenzuela T. Efficacy of progressive resistance training interventions in older adults in nursing homes: a systematic review. J Am Med Dir Assoc. 2012;13:418-28.

53. Giné-Garriga $M$, Roqué-Figuls $M$, Coll-Planas L, Sitjà-Rabert $M$, Salva A. Physical exercise interventions for improving performance-based measures of physical function in community-dwelling, frail older adults: A systematic review and meta-analysis. Arch Phys Med Rehabil. 2014;95:753-69.

54. Keogh JWL, Kilding A, Pidgeon P, Ashley L, Gillis D. Physical benefits of dancing for healthy older adults: a review. J Aging Phys Act. 2009;17:479-500.

55. Latham NK, Bennett DA, Stretton CM, Anderson CS. Systematic review of progressive resistance strength training in older adults. J Gerontol A Biol Sci Med Sci. 2004;59:48-61. 